\title{
RESPONSE OF OAT CULTIVARS TO ETHEPHON AND BORON
}

\section{A. M. S. Addaheri \\ Lecturer \\ N. M. Abood \\ Prof.}

Department of Field Crops, College of Agriculture, University of Anbar, Iraq ag.abdullah.mahmood@uoanbar.edu.iq

\section{ABSTRACT}

The aim of this study was to reduce the lodging and improve grain yield by evaluation the performance of some oat cultivars introduced into Iraq. A field experiment was conducted during two seasons of 2017-2018 and 2018-2019, included four cultivars (Genzania, Shafa, Carrolup and Hamel) under the influence of foliar spraying of ethephon at concentrations of 0,500 and $1000 \mathrm{ppm}$, and foliar application of boron with concentrations of 0,50 and 100 ppm. Using RCBD within split-split arrangement and three replicates. The results were revealed that Genzania was recorded the highest number of grains head ${ }^{-1}$ and grain yield 6.512 and $5.565 \mathrm{t} \mathrm{ha}^{-1}$ in the two seasons respectively. Shafa had the highest number of active tillers $\mathrm{m}^{-2}$ in both seasons and the highest single grain weight in the second season. Carrolup was produced the highest single grain weight in the first season. Spraying ethephon with concentrations of 500 and $1000 \mathrm{ppm}$ increased stem diameter and number of active tillers $\mathrm{m}^{-2}$ for both seasons. Spraying $500 \mathrm{ppm}$ of ethephon increased grain yield in the first season and reduced lodging rate in the second season. Ethephon with $1000 \mathrm{ppm}$ reduced lodging rate in both seasons. Foliar application of boron with concentrations of 50 and $100 \mathrm{ppm}$ increased plant height and grain yield in both seasons.

Key words: lodging, active tillers, grain yield.

Part of Ph.D. Dissertation of the $1^{\text {st }}$ author.

الأهري وعبود 268-259:(1)51:2020 مجلة العلوم الزراعية العراقية

إستجابة أصناف من الثوفان للأثيفون والبورون

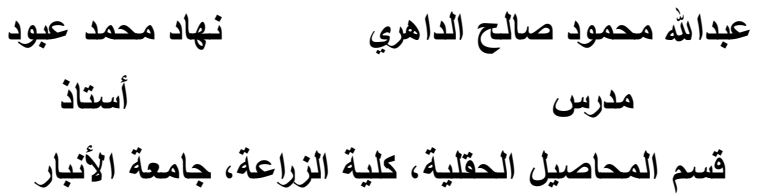

المستخلص

تهدف هذه الدراسة إلى الحد من الاضطجاع وتحسين حاصل الحبوب وتقييم أداء بعض أصناف الشوفان المدخلة إلى العراق.

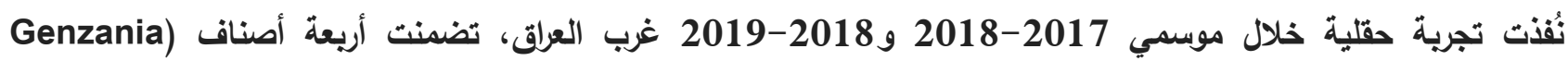

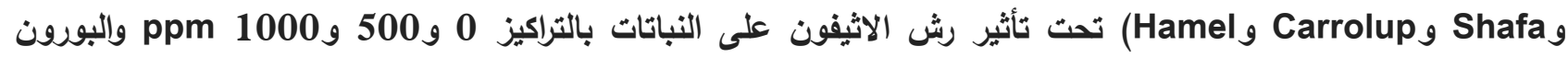
بالتراكيز 0 و50 و 9.ppm أظهرت النتائج تسجيل Genzania أعلى عدد حبوب بالدالية واعلى حاصل حبوب بلغ 6.512 و 5.565 طن هـ -1 للموسمين بالتتابع. أعطى Shafa أعلى عدد أثطاء فعالة في المتر المربع للموسمين وأعلى

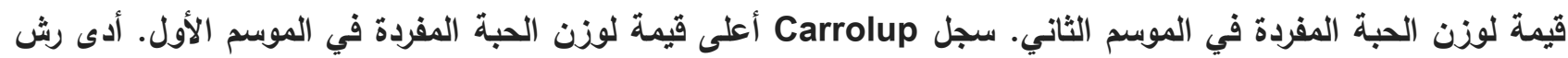
الاثيفون بالتركيزين 500 وppm إلى زيادة قطر الساق وعدد الأشطاء الفعالة لكلا الموسمين. حقى رش لش الاثيفون

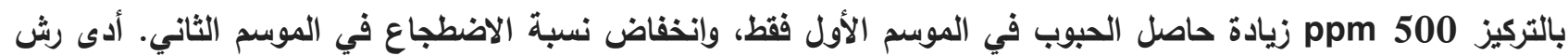

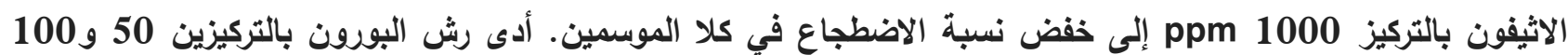
إلى زيادة ارتفاع النبات وحاصل الحبوب في كلا الموسمين. كلمات مفتاحية: اضطجاع، أشطاء فعالة، حاصل الحبوب. جزء من أطروحة دكتوراه للباحث الأول

\footnotetext{
*Received:11/6/2019, Accepted:8/9/2019
} 


\section{INTRODUCTION}

Oat (Avena sativa L.) is an important and multipurpose crop, with major use for food and feed. Despite the importance of oat in the world, it is not grown in Iraq at the level of economic production, so some oat cultivars was introduced for the cultivation of locally, but was observed that these cultivars have a lodging problem. Yield quantity and quality are negatively affected by lodging (6). Ethephon (2-chloroethyl phosphonic acid) is one of plant growth regulator that turns out to be beneficial for shorten the plants and control lodging of wheat (25), and other studies have indicated that ethephon decreases plant height and increases stem diameter of maize, and caused less lodging $(21,26)$. In addition to that, Taylor et al., (24) pointed out that ethephon increased the active tillers in barley. Boron is one of the important micronutrient elements for plants, performing functions related to carbohydrate metabolism, phenol metabolism, indole acetic acid metabolism, sugar transport, respiration, membrane transport, cell wall synthesis, cell wall lignification and cell wall structure (7). The functions of boron, especially related to the lignification, could be a role in strengthening the stem of plants, and reducing the lodging, along with other functions that contribute to enhanced the yield. This study was aimed to investigate the effect of ethephon and boron on the lodging and some other traits correlated with the grain yield of some oat cultivars, which introduced into Iraq.

\section{MATERIALS AND METHODS}

A field experiment was conducted during two winter seasons of 2017-2018 and 2018-2019, in western of Iraq, $100 \mathrm{~km}$ from Baghdad, at the research station, College of Agriculture, University of Anbar. The Randomize Complete Block Design (RCBD) was used according to the split-split plot arrangement, with three replicates. Boron (B) concentrations (0, 50 and $100 \mathrm{ppm})$ was occupied the whole plots, while ethephon (E) concentrations (0, 500 and $1000 \mathrm{ppm}$ ) in the split plots, and four cultivars of oat (Genzania, Shafa, Carrolup and Hamel) in the split-split plots. Random soil samples were taken from the soil of experiment at the depth of $0-30 \mathrm{~cm}$ and analyzed, as shows in Table 1 , the results of some chemical and physical properties.

Table 1. Results of soil analysis

\begin{tabular}{|c|c|c|}
\hline \multirow{2}{*}{ analysis type } & \multicolumn{2}{|c|}{ Results } \\
\hline & $2017-2018$ & 2018-2019 \\
\hline EC & $1.50 \mathrm{dS} \mathrm{m}^{-1}$ & $1.60 \mathrm{dS} \mathrm{m}^{-1}$ \\
\hline pH. & 7.82 & 7.97 \\
\hline Sand & \multicolumn{2}{|c|}{$312 \mathrm{~g} \mathrm{~kg}^{-1}$} \\
\hline Clay & \multicolumn{2}{|c|}{$26 \mathrm{~g} \mathrm{~kg}^{-1}$} \\
\hline Silt & \multicolumn{2}{|c|}{$662 \mathrm{~g} \mathrm{~kg}^{-1}$} \\
\hline Texture & \multicolumn{2}{|c|}{ Silt loam } \\
\hline Bulk density & \multicolumn{2}{|c|}{$1.3 \mathrm{~g} \mathrm{~cm}^{-3}$} \\
\hline B extracted by hot water & $0.36 \mathrm{mg} \mathrm{kg}^{-1}$ & $0.41 \mathrm{mg} \mathrm{kg}^{-1}$ \\
\hline Total nitrogen & $126.40 \mathrm{mg} \mathrm{kg}^{-1}$ & $112.94 \mathrm{mg} \mathrm{kg}^{-1}$ \\
\hline Available phosphor & $7.05 \mathrm{mg} \mathrm{kg}^{-1}$ & $6.74 \mathrm{mg} \mathrm{kg}^{-1}$ \\
\hline Available Potassium & $144 \mathrm{mg} \mathrm{kg}^{-1}$ & $132 \mathrm{mg} \mathrm{kg}^{-1}$ \\
\hline Organic matter & $0.55 \%$ & $0.53 \% 0$ \\
\hline CEC & $19 \mathrm{cmol}_{\mathrm{c}} \mathrm{kg}^{-1}$ & $17 \mathrm{cmol}_{\mathrm{c}} \mathrm{kg}^{-1}$ \\
\hline
\end{tabular}

The experimental field was plowed, disked, then was divided into units (plots) of $3 \times 2.5 \mathrm{~m}$, the seeds were planted in the late November, with 10 lines in each unit, with seeding rate of $100 \mathrm{~kg} \mathrm{ha}^{-1}$. Triple super phosphate $(45 \%$ $\left.\mathrm{P}_{2} \mathrm{O}_{5}\right)$ as granular fertilizer was applied at rate of $100 \mathrm{~kg} \mathrm{P} \mathrm{ha}{ }^{-1}$ with one dose prior to planting, and urea $(46 \% \mathrm{~N})$ as granular fertilizer was applied at rate of $150 \mathrm{~kg} \mathrm{~N}^{-1}$ with three doses at emergence, tillering and booting. Ethephon (48\% 2-chloroethyl phosphonic acid) was sprayed on the plants at ZGS15 and ZGS20, as well foliar application of boron as boric acid $\left(\mathrm{H}_{3} \mathrm{BO}_{3}, 17 \% \mathrm{~B}\right)$ was performed at ZGS41 and ZGS61, according to Zadoks et al., (28). Studied traits: Plant height $(\mathrm{cm})$, from the main shoot of ten randomly selected plants was measured from the soil surface to the bottom of the panicle, at $100 \%$ flowering. Stem diameter (mm), at $100 \%$ flowering, ten plants were randomly selected to measure stem of main shoots at the bottom, middle and top. Lodging rate (\%), it was assessed at maturity by measured the lodging area, with a rate calculated using the formula: lodging rate $=($ lodging area $/$ plot area $) \times 100$, described by Chen et al., (12). Number of active tillers $\mathrm{m}^{-2}$, it is the number of heads in the central square meter. Number of grains head $^{-1}$, it was calculated in ten randomize heads from the central square meter. Single grain weight $(\mathrm{mg})$, it is 1000 grain weight dried at $65^{\circ} \mathrm{C}$ for 72 hours, divided by 1000 . Grain yield $\left(\mathrm{t} \mathrm{ha}^{-1}\right)$, it is the weight of grain yield of central square meter, which was dried at $65^{\circ} \mathrm{C}$ for 72 hours, multiplied by 10000 .

\section{RESULTS AND DISCUSSION}

Plant height (cm): Results in Table 2 shows that Genzania produced the highest plant 
height, reached 90.4 and $100.5 \mathrm{~cm}$ significantly higher than the other cultivars except Hamel in the first season, while Shafa had the lowest plant height 85.8 and $89.4 \mathrm{~cm}$ in two seasons respectively. The differences among cultivars in the plant height could be due to the differences in genotype and the differences in the response to environmental conditions and how to take advantage of the available nutrients, which reflected the increase in plant height. This result is consistent with the results of Midha et al., (19) and Dabhi et al., (13) in oat. Results in Table 2 shows that the ethephon reduced plant height. The control ( $0 \mathrm{ppm}$ ethephon) recorded the highest value 93.5 and $100.4 \mathrm{~cm}$ for the two seasons respectively. Ethephon spraying with concentrations of 500 and 1000 ppm caused significant decreases with $5.56 \%$ and $12.19 \%$ in the first season, $11.35 \%$ and $10.85 \%$ respectively in the second season. The reason could be due to ethylene, which inhibits cell division in the stem. This result is similar to what found in wheat (27) and barley $(24,23)$. Boron increased plant height (Table 2), as the control (0 ppm boron) recorded the lowest value, reached 83.0 and $87.9 \mathrm{~cm}$ in the two season respectively, and the boron concentrations of 50 and $100 \mathrm{ppm}$ increased plant height significantly with 8.0 and $7.0 \mathrm{~cm}$ in the first season, 6.3 and $8.9 \mathrm{~cm}$ in the second season, but concentrations of 50 and $100 \mathrm{ppm}$ were not significantly different in the two seasons. The increased plant height was probably due to the positive role of boron in the plant's vital processes (7). Similar results found by Al-Naqeeb and Hashim (3) about increase plant height of wheat due to effect of boron. Table 2 shows significant effects of the interaction between the cultivars and the ethephon concentrations on the plant height in both seasons. The combination of Hamel with $0 \mathrm{ppm}$ ethephon was highest plant height

Table 2. Effect of boron and ethephon on the plant height $(\mathrm{cm})$ of four oat cultivars

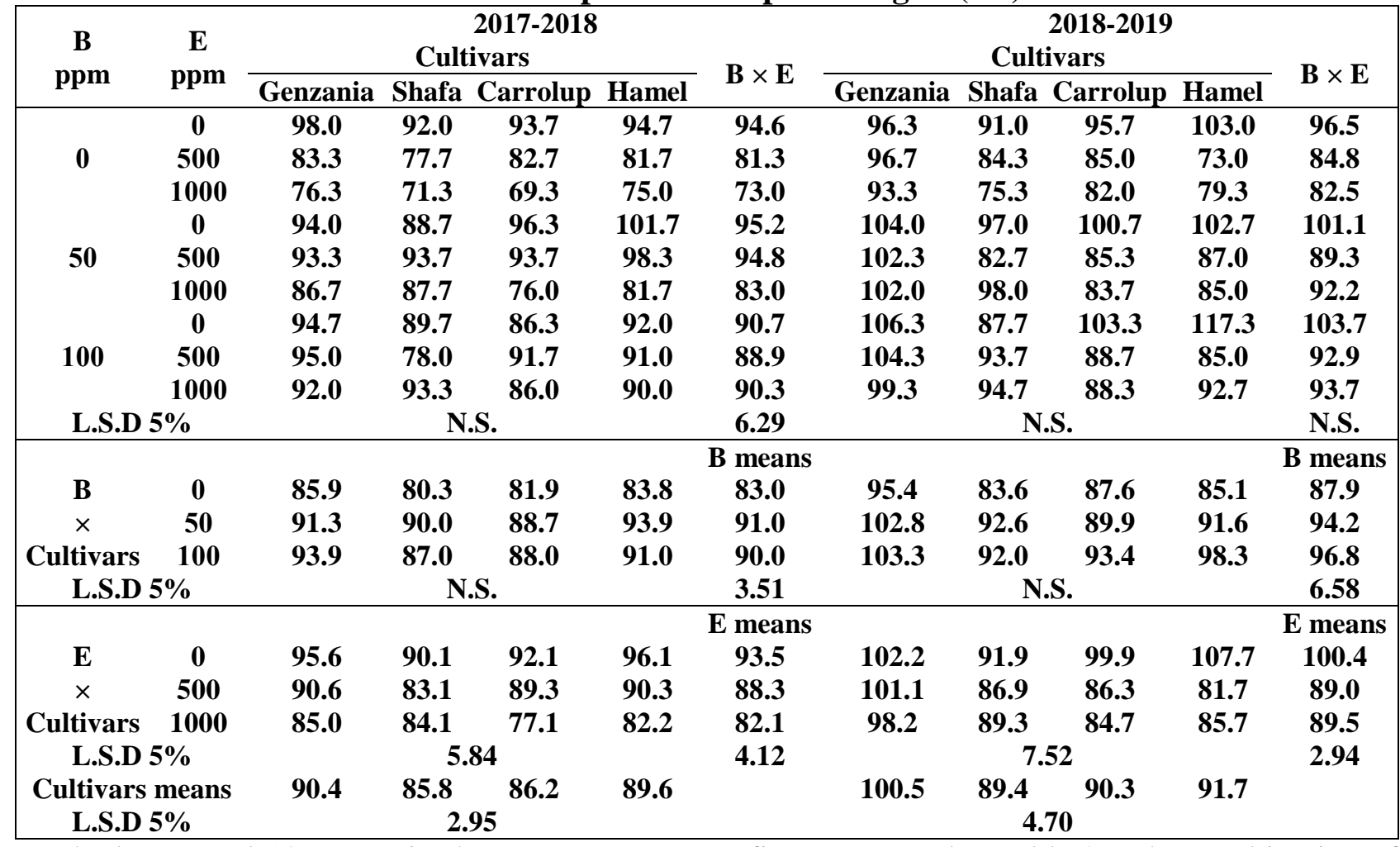

reached 96.1 and $107.7 \mathrm{~cm}$ in the two seasons respectively, while Carrolup with $1000 \mathrm{ppm}$ ethephon recorded the lowest value $(77.1 \mathrm{~cm})$ in the first season, Hamel with $500 \mathrm{ppm}$ ethephon recorded the lowest value $(81.7 \mathrm{~cm})$ in the second season. The effect of interaction between the concentrations of boron and ethephon on plant height was significant in the first season only (Table 2). The combination of $0 \mathrm{ppm}$ ethephon with $50 \mathrm{ppm}$ boron recorded the highest mean, reached $95.2 \mathrm{~cm}$, and the combination of $1000 \mathrm{ppm}$ ethephon with 0 ppm boron recorded the lowest mean, reached $73.0 \mathrm{~cm}$.

Stem diameter $(\mathbf{m m})$ : The results in Table 3 indicates that Hamel has greatest value of stem 
diameter 6.28 and $5.97 \mathrm{~mm}$, significantly higher than the other cultivars, while Shafa recorded the lowest value 3.80 and $3.56 \mathrm{~mm}$ in the two seasons respectively. The difference of stem diameter could be due to different of genotype. Sampson (20) obtained similar results, as stem diameter of oat genotypes was different: Attia et al., (5) found similar results in wheat genotypes. The results in the Table 3 shows that the ethephon was increased the stem diameter. The highest value of stem diameter was recorded at the concentration of $500 \mathrm{ppm}$ ethephon were 4.89 and $4.84 \mathrm{~mm}$ for the two seasons respectively, which did not significantly different from the concentration of $1000 \mathrm{ppm}$ ethephon, but both concentrations differed significantly with control (0 ppm ethephon) that has the lowest value of stem diameter of 4.22 and $4.49 \mathrm{~mm}$ in the two seasons respectively. This result is consistent with the results of Chandiposha and Chivende (10) in maize, and Abood (1) in sorghum, about increase stem diameter by ethephon effect. Boron application increased stem diameter significantly in the first season (Table 3). The concentration of $100 \mathrm{ppm}$ of boron recorded the highest mean, reached 4.89 $\mathrm{mm}$ and did not differ significantly from the concentration $50 \mathrm{ppm}$ boron $(4.79 \mathrm{~mm})$, but the two concentrations differed significantly from the $0 \mathrm{ppm}$ boron, which recorded the lowest mean $(4.28 \mathrm{~mm})$. The increase of stem diameter could be due to the role of boron in the lignification (7).

Table 3. Effect of boron and ethephon on the stem diameter ( $\mathrm{mm}$ ) of four oat cultivars

\begin{tabular}{|c|c|c|c|c|c|c|c|c|c|c|c|}
\hline \multirow{3}{*}{$\begin{array}{c}\text { B } \\
\text { ppm }\end{array}$} & \multirow{3}{*}{$\begin{array}{c}\mathbf{E} \\
\mathbf{p p m}\end{array}$} & \multicolumn{5}{|c|}{$2017-2018$} & \multicolumn{5}{|c|}{ 2018-2019 } \\
\hline & & \multicolumn{4}{|c|}{ Cultivars } & \multirow{2}{*}{$\mathbf{B} \times \mathbf{E}$} & \multicolumn{4}{|c|}{ Cultivars } & \multirow{2}{*}{$\mathbf{B} \times \mathbf{E}$} \\
\hline & & Genzania & Shafa & Carrolup & Hamel & & Genzania & Shafa & Carrolup & Hamel & \\
\hline \multirow{3}{*}{$\mathbf{0}$} & $\mathbf{0}$ & 4.53 & 3.04 & 3.83 & 6.05 & 4.36 & 4.60 & 3.27 & 3.08 & 5.18 & 4.03 \\
\hline & 500 & 4.51 & 3.30 & 3.67 & 6.61 & 4.52 & 4.57 & 4.45 & 4.20 & 6.25 & 4.87 \\
\hline & 1000 & 3.18 & 3.25 & 3.25 & 6.18 & 3.96 & 5.48 & 3.25 & 4.73 & 5.25 & 4.68 \\
\hline \multirow{4}{*}{50} & $\mathbf{0}$ & 4.93 & 2.98 & 2.76 & 5.87 & 4.14 & 5.80 & 3.28 & 4.20 & 6.37 & 4.91 \\
\hline & 500 & 5.64 & 3.75 & 4.43 & 6.63 & 5.11 & 4.92 & 3.75 & 4.67 & 5.95 & 4.82 \\
\hline & 1000 & 3.90 & 4.45 & 4.45 & 7.65 & 5.12 & 5.50 & 3.67 & 4.83 & 5.67 & 4.92 \\
\hline & $\mathbf{0}$ & 4.49 & 3.44 & 3.26 & 5.43 & 4.16 & 5.02 & 3.43 & 4.02 & 5.63 & 4.52 \\
\hline \multirow[t]{2}{*}{100} & 500 & 5.84 & 4.20 & 4.28 & 5.78 & 5.02 & 4.82 & 3.43 & 3.48 & 7.57 & 4.82 \\
\hline & 1000 & 5.09 & 5.82 & 4.78 & 6.27 & 5.49 & 4.48 & 3.52 & 4.82 & 5.90 & 4.68 \\
\hline \multicolumn{2}{|c|}{ L.S.D 5\% } & \multicolumn{3}{|c|}{ N.S. } & \multirow{2}{*}{\multicolumn{2}{|c|}{0.540}} & \multicolumn{4}{|c|}{0.895} & N.S. \\
\hline & & & & & & & & & & & B means \\
\hline B & $\mathbf{0}$ & 4.07 & 3.19 & 3.58 & 6.28 & 4.28 & 4.88 & 3.66 & 4.01 & 5.56 & 4.53 \\
\hline$x$ & 50 & 4.82 & 3.73 & 3.88 & 6.72 & 4.79 & 5.41 & 3.57 & 4.57 & 5.99 & 4.88 \\
\hline Cultivars & 100 & 5.14 & 4.49 & 4.11 & 5.83 & 4.89 & 4.77 & 3.46 & 4.11 & 6.37 & 4.68 \\
\hline \multicolumn{2}{|c|}{ L.S.D $5 \%$} & \multicolumn{3}{|c|}{ N.S. } & \multirow{2}{*}{\multicolumn{2}{|c|}{0.277}} & \multicolumn{4}{|c|}{0.564} & N.S. \\
\hline & & & & & & & & & & & E means \\
\hline $\mathbf{E}$ & $\mathbf{0}$ & 4.65 & 3.15 & 3.28 & 5.79 & 4.22 & 5.14 & 3.33 & 3.77 & 5.73 & 4.49 \\
\hline$x$ & 500 & 5.33 & 3.75 & 4.13 & 6.34 & 4.89 & 4.77 & 3.88 & 4.12 & 6.59 & 4.84 \\
\hline \multirow{4}{*}{\multicolumn{2}{|c|}{$\begin{array}{c}\text { Cultivars } 1000 \\
\text { L.S.D 5\% } \\
\text { Cultivars means } \\
\text { L.S.D 5\% } \\
\end{array}$}} & 4.06 & 4.51 & 4.16 & 6.70 & 4.86 & 5.16 & 3.48 & 4.79 & 5.61 & 4.76 \\
\hline & & \multicolumn{3}{|c|}{0.872} & & \multirow[t]{3}{*}{0.359} & \multicolumn{4}{|c|}{0.501} & 0.273 \\
\hline & & 4.68 & 3.80 & 3.86 & 6.28 & & 5.02 & 3.56 & 4.23 & 5.97 & \\
\hline & & & 0.5 & 41 & & & & 0.2 & 290 & & \\
\hline
\end{tabular}

The interaction of cultivars and ethephon concentrations showed a significant effect on stem diameter for both seasons (Table 3). Hamel recorded the highest value of stem diameter $(6.70 \mathrm{~mm})$ when sprayed with 1000 ppm of ethephon in the first season, and the same cultivar recorded the highest value (6.59 $\mathrm{mm}$ ) when sprayed with the concentration of $500 \mathrm{ppm}$ of ethephon in the second season, while Shafa sprayed with a concentration of 0 ppm of ethephon recorded the lowest value 3.15 and $3.33 \mathrm{~mm}$ in the two season respectively.Table 3 shows that the triple interaction of the factors (Boron $\times$ Ethephon $\times$ Cultivars) had a significant effect on stem diameter for the second season only, as Hamel with $500 \mathrm{ppm}$ of ethephon and $100 \mathrm{ppm}$ of boron has the highest value $(7.57 \mathrm{~mm})$, while Carrolup with $0 \mathrm{ppm}$ of ethephon and $0 \mathrm{ppm}$ of boron has the lowest value $(3.08 \mathrm{~mm})$.

\section{Lodging rate (\%)}

The data of lodging rate in the Table 4 indicates that the cultivars were differed significantly in the first season only. Shafa recorded the lowest lodging rate $(7.70 \%)$, did not different significantly from Hamel, while 
Genzania recorded the highest lodging rate $(9.59 \%)$ and did not differed significantly from Carrolup. This difference is due to the different traits associated with lodging resistance, such as plant height, Shafa was lowest plant height (Table 2) and with lowest lodging, but Genzania was highest plant height and highest lodging. This is consistent with Kelbert et al., (17) who revealed that the short wheat plants were more resistant to lodging. The results were consistent with the results obtained by Ali et al., (2) and Arenhardt et al., (4) about the different lodging of oat genotypes. The results in Table 4 show that the ethephon spraying led to significant decreases lodging rate in both seasons. The control $(0$ ppm ethephon) recorded the highest average of lodging rate, reached $9.48 \%$ and $13.45 \%$ for the two seasons respectively, and lodging rate decreased significantly in the first season, by spraying ethephon with concentration of 1000 ppm was recorded the lowest average (7.53\%). In the second season, lodging rate decreased significantly by spraying ethephon with concentrations of 500 and 1000 ppm, which recorded the lowest average, reached $9.75 \%$ and $9.98 \%$ for the two concentrations respectively. These decreases could be occurred due to reduction in plant height by ethephon (Table 2). This is consistent with the findings of Shekoofa and Emam (21) and Wei et al., (26), as well the result is consistent with results obtained in wheat $(25,27)$ and barley (24). There were significant effects of the interaction between the cultivars and ethephon concentrations on lodging rate in both seasons (Table 4). In the first season, Genzania with concentration of $1000 \mathrm{ppm}$ ethephon had the lowest value of lodging rate $(5.95 \%)$, and the same cultivar without ethephon recorded the highest value (13.49\%). In the second season, Hamel with 500 ppm ethephon had the lowest value of lodging rate $(7.33 \%)$, and Genzania without ethephon had the highest value $(14.71 \%)$. The data of lodging rate in the Table 4 shows that there is a significant effect of the triple interaction of the study factors in the second season only. Shafa sprayed with ethephon at $1000 \mathrm{ppm}$ and boron at $50 \mathrm{ppm}$ recorded the lowest lodging rate, reached $6.42 \%$, While Hamel with 0 ppm of ethephon and $50 \mathrm{ppm}$ of boron recorded the highest lodging rate, reached $20 \%$.

Table 4. Effect of boron and ethephon on the lodging rate $(\%)$ of four oat cultivars

\begin{tabular}{|c|c|c|c|c|c|c|c|c|c|c|c|}
\hline \multirow{3}{*}{$\begin{array}{c}\text { B } \\
\text { ppm }\end{array}$} & \multirow{3}{*}{$\begin{array}{c}\mathbf{E} \\
\mathbf{p p m}\end{array}$} & \multicolumn{5}{|c|}{ 2017-2018 } & \multicolumn{5}{|c|}{ 2018-2019 } \\
\hline & & \multicolumn{4}{|c|}{ Cultivars } & \multirow{2}{*}{$\mathbf{B} \times \mathbf{E}$} & \multicolumn{4}{|c|}{ Cultivars } & \multirow{2}{*}{$\mathbf{B} \times \mathbf{E}$} \\
\hline & & Genzania & Shafa & Carrolup & Hamel & & Genzania & Shafa & Carrolup & Hamel & \\
\hline \multirow{3}{*}{ 0 } & 0 & 12.62 & 6.97 & 10.17 & 5.74 & 8.87 & 10.56 & 18.49 & 7.69 & 12.14 & 12.22 \\
\hline & 500 & 11.44 & 9.80 & 9.94 & 7.72 & 9.73 & 13.78 & 10.27 & 14.31 & 6.49 & 11.21 \\
\hline & 1000 & 6.68 & 7.37 & 10.21 & 9.79 & 8.51 & 10.32 & 8.93 & 11.78 & 12.41 & 10.86 \\
\hline \multirow{3}{*}{50} & 0 & 14.21 & 6.40 & 11.20 & 7.66 & 9.87 & 14.04 & 10.36 & 12.96 & 20.00 & 14.34 \\
\hline & 500 & 7.72 & 8.90 & 6.70 & 8.41 & 7.93 & 11.56 & 10.31 & 8.76 & 7.80 & 9.61 \\
\hline & 1000 & 3.35 & 6.91 & 5.17 & 8.53 & 5.99 & 10.33 & 6.42 & 11.27 & 11.53 & 9.89 \\
\hline \multirow{3}{*}{100} & $\mathbf{0}$ & 13.65 & 7.27 & 11.59 & 6.34 & 9.71 & 19.53 & 13.88 & 11.72 & 11.09 & 14.05 \\
\hline & 500 & 8.84 & 5.95 & 9.35 & 6.77 & 7.73 & 8.98 & 8.47 & 8.53 & 7.70 & 8.42 \\
\hline & 1000 & 7.82 & 9.73 & 6.28 & 8.55 & 8.09 & 7.65 & 11.04 & 10.47 & 7.65 & 9.20 \\
\hline \multicolumn{2}{|c|}{ L.S.D $5 \%$} & \multicolumn{3}{|c|}{ N.S } & \multicolumn{2}{|r|}{ N.S. } & \multicolumn{4}{|c|}{7.195} & \multirow{2}{*}{$\frac{\text { N.S. }}{\text { B means }}$} \\
\hline & & & & & & B means & & & & & \\
\hline B & 0 & 10.24 & 8.05 & 10.10 & 7.75 & 9.04 & 11.55 & 12.56 & 11.26 & 10.35 & 11.43 \\
\hline$x$ & 50 & 8.43 & 7.40 & 7.69 & 8.20 & 7.93 & 11.97 & 9.03 & 10.99 & 13.11 & 11.28 \\
\hline Cultivars & 100 & 10.10 & 7.65 & 9.07 & 7.22 & 8.51 & 12.05 & 11.13 & 10.24 & 8.81 & 10.56 \\
\hline \multicolumn{2}{|c|}{ L.S.D $5 \%$} & \multicolumn{3}{|c|}{ N.S. } & \multirow{2}{*}{\multicolumn{2}{|c|}{$\frac{\text { N.S. }}{\text { E means }}$}} & \multicolumn{3}{|c|}{ N.S. } & & N.S. \\
\hline & & & & & & & & & & \multicolumn{2}{|r|}{ E means } \\
\hline $\mathbf{E}$ & $\mathbf{0}$ & 13.49 & 6.88 & 10.99 & 6.58 & 9.48 & 14.71 & 14.24 & 10.79 & 14.41 & 13.54 \\
\hline$x$ & 500 & 9.33 & 8.22 & 8.66 & 7.63 & 8.46 & 11.44 & 9.68 & 10.53 & 7.33 & 9.75 \\
\hline & & 5.95 & 8.00 & 7.22 & 8.96 & 7.53 & 9.43 & 8.80 & 11.18 & 10.53 & 9.98 \\
\hline \multirow{3}{*}{\multicolumn{2}{|c|}{$\begin{array}{c}\text { L.S.D 5\% } \\
\text { Cultivars means } \\
\text { L.S.D } 5 \%\end{array}$}} & \multicolumn{3}{|c|}{1.933} & & \multirow[t]{3}{*}{1.162} & \multicolumn{3}{|c|}{3.982} & & \multirow[t]{3}{*}{3.211} \\
\hline & & 9.59 & 7.70 & 8.96 & 7.72 & & 11.86 & 10.91 & 10.83 & 10.76 & \\
\hline & & \multicolumn{4}{|c|}{1.077} & & \multicolumn{4}{|c|}{ N.S. } & \\
\hline
\end{tabular}

Number of active tillers $\mathbf{~ m}^{-2}$ tillers $\mathrm{m}^{-2}$, reached 434 and 346 tillers $\mathrm{m}^{-2}$,

The results in the Table 5 shows that Shafa was produced the highest number of active significantly higher than Genzania and Hamel, while Hamel had the lowest average, reached 
338 and 302 in the two seasons respectively. This result corresponds to the results of Maral et al., (18) in relation to the different oat genotypes in the number of active tillers per unit area. The data shows that the number of active tillers $\mathrm{m}^{-2}$ was increased significantly over the control at ethephon concentrations 500 and 1000 ppm with $8.80 \%$ and $6.93 \%$ in the first season, $14.91 \%$ and $16.61 \%$ in the second season (Table 5). This could be because promote tillering due to inhibition the growth in the main stem of plant (16). Similar results was found by Taylor et al., (24) that number of active tillers of barley increased by ethephon effect. The effect of interaction between cultivars and ethephon concentrations was significant on the number of active tillers $\mathrm{m}^{-2}$ in both seasons (Table 5). Shafa with ethephon at concentration of $1000 \mathrm{ppm}$ recorded the highest number of active tillers $\mathrm{m}^{-2}$, reached 456 and 380 tillers $\mathrm{m}^{-2}$, while Hamel without ethephon $(0 \mathrm{ppm})$ recorded the lowest number, reached 318 and 264 tillers $\mathrm{m}^{-2}$ for the two seasons respectively. The results in the Table 5 indicates that there was a significant effect of the interaction between the ethephon and boron concentrations on the number of active tillers $\mathrm{m}^{-2}$ in the first season only, as combination of $500 \mathrm{ppm}$ of ethephon with $0 \mathrm{ppm}$ of boron produced the highest average (412 tillers $\left.\mathrm{m}^{-2}\right)$, while the combination of $0 \mathrm{ppm}$ of ethephon with 100 ppm of boron had the lowest average (371 tillers $\mathrm{m}^{-2}$ ).

Table 5. Effect of boron and ethephon on the Number of active tillers $\mathrm{m}^{-2}$ of four oat cultivars

\begin{tabular}{|c|c|c|c|c|c|c|c|c|c|c|c|}
\hline \multirow{3}{*}{$\begin{array}{c}\text { B } \\
\text { ppm }\end{array}$} & \multirow{3}{*}{$\begin{array}{c}\mathbf{E} \\
\mathbf{p p m}\end{array}$} & \multicolumn{5}{|c|}{ 2017-2018 } & \multicolumn{5}{|c|}{ 2018-2019 } \\
\hline & & \multicolumn{4}{|c|}{ Cultivars } & \multirow{2}{*}{$\mathbf{B} \times \mathbf{E}$} & \multicolumn{4}{|c|}{ Cultivars } & \multirow{2}{*}{$\mathbf{B} \times \mathbf{E}$} \\
\hline & & Genzania & Shafa & Carrolup & Hamel & & Genzania & Shafa & Carrolup & Hamel & \\
\hline \multirow{3}{*}{ 0 } & 0 & 362 & 393 & 425 & 326 & 376 & 327 & 283 & 352 & 274 & 309 \\
\hline & 500 & 381 & 455 & 462 & 350 & 412 & 328 & 364 & 315 & 315 & 331 \\
\hline & 1000 & 378 & 464 & 374 & 342 & 390 & 306 & 367 & 340 & 332 & 336 \\
\hline \multirow{3}{*}{50} & $\mathbf{0}$ & 365 & 395 & 426 & 321 & 377 & 318 & 323 & 269 & 265 & 294 \\
\hline & 500 & 390 & 455 & 424 & 344 & 403 & 351 & 361 & 384 & 315 & 353 \\
\hline & 1000 & 396 & 446 & 406 & 358 & 401 & 291 & 391 & 363 & 314 & 340 \\
\hline \multirow{3}{*}{100} & $\mathbf{0}$ & 358 & 393 & 425 & 308 & 371 & 268 & 281 & 327 & 253 & 282 \\
\hline & 500 & 392 & 445 & 460 & 344 & 410 & 348 & 366. & 316 & 303 & 333 \\
\hline & 1000 & 383 & 457 & 450 & 353 & 411 & 314 & 381 & 374 & 350 & 355 \\
\hline \multicolumn{2}{|c|}{ L.S.D 5\% } & \multicolumn{3}{|c|}{ N.S. } & \multirow{2}{*}{\multicolumn{2}{|c|}{$\begin{array}{c}12.1 \\
\text { B means }\end{array}$}} & \multicolumn{4}{|c|}{ N.S. } & N.S. \\
\hline & & & & & & & & & & & B means \\
\hline B & $\mathbf{0}$ & 374 & 437 & 420 & 339 & 393 & 320 & 338 & 336 & 307 & 325 \\
\hline$x$ & 50 & 384 & 432 & 419 & 341 & 394 & 320 & 358 & 339 & 298 & 329 \\
\hline Cultivars & 100 & 378 & 432 & 445 & 335 & 397 & 310 & 343 & 339 & 302 & 323 \\
\hline \multicolumn{2}{|c|}{ L.S.D 5\% } & \multicolumn{3}{|c|}{ N.S. } & \multirow{2}{*}{\multicolumn{2}{|c|}{$\frac{\text { N.S. }}{\text { E means }}$}} & \multirow{2}{*}{\multicolumn{4}{|c|}{ N.S. }} & N.S. \\
\hline & & & & & & & & & & & E means \\
\hline $\mathbf{E}$ & $\mathbf{0}$ & 362 & 394 & 425 & 318 & 375 & 304 & 296 & 316 & 264 & 295 \\
\hline$x$ & 500 & 388 & 452 & 448 & 346 & 408 & 342 & 364 & 338 & 311 & 339 \\
\hline \multirow{3}{*}{\multicolumn{2}{|c|}{$\begin{array}{c}\text { Cultivars } \\
\text { L.S.D 5\% } \\
\text { Cultivars means } \\
\text { L.S.D 5\% }\end{array}$}} & 386 & 456 & 410 & 351 & 401 & 304 & 380 & 359 & 332 & 344 \\
\hline & & \multicolumn{4}{|c|}{19.6} & 5.8 & \multicolumn{4}{|c|}{37.5} & 25.7 \\
\hline & & 378 & $\begin{array}{r}434 \\
1\end{array}$ & $2.6^{428}$ & 338 & & 317 & $\begin{array}{l}346 \\
19\end{array}$ & $.4^{338}$ & 302 & \\
\hline
\end{tabular}

\section{Number of grains head ${ }^{-1}$}

Significant differences were found among cultivars in the number of grains head ${ }^{-1}$ (Table 6). Genzania had the highest average, reached 69.6 and 76.0 grains head $^{-1}$, significantly higher than all other cultivars in the first season, and higher than Shafa and Carrolup in the second season, while Carrolup had the lowest average, reached 39.0 and 43.4 grains head $^{-1}$ for the two seasons respectively. This finding agree with the results found by Siloriya et al., (22), and Dumlupinar et al.,
(14) about the different of grains head ${ }^{-1}$ in oat genotypes. Foliar application of boron in the first season with concentrations of 50 and 100 ppm resulted in significant increases number of grains head $^{-1}$ than in control with $15.08 \%$ and $16.52 \%$ respectively, but the concentrations 50 and $100 \mathrm{ppm}$ did not differed significantly (Table 6). The results in Table 6 indicated there were significant effects of the interaction between ethephon and boron on the number of grains head ${ }^{-1}$ in both seasons. In the first season, the combination of 500 
ppm ethephon with $50 \mathrm{ppm}$ boron produced the highest value (58.3 grains head ${ }^{-1}$ ), while the combination of $1000 \mathrm{ppm}$ ethephon with 0 ppm boron had the lowest value (46.8 grains head $\left.^{-1}\right)$. In the second season, the combination of $0 \mathrm{ppm}$ ethephon with $100 \mathrm{ppm}$ boron produced the highest value (64.6 grains head $^{-}$ ${ }^{1}$ ), while the combination $500 \mathrm{ppm}$ ethephon with $0 \mathrm{ppm}$ boron had the lowest value (56.2 grains head $^{-1}$ ).

Table 6. Effect of boron and ethephon on the Number of grains head ${ }^{-1}$ of four oat cultivars

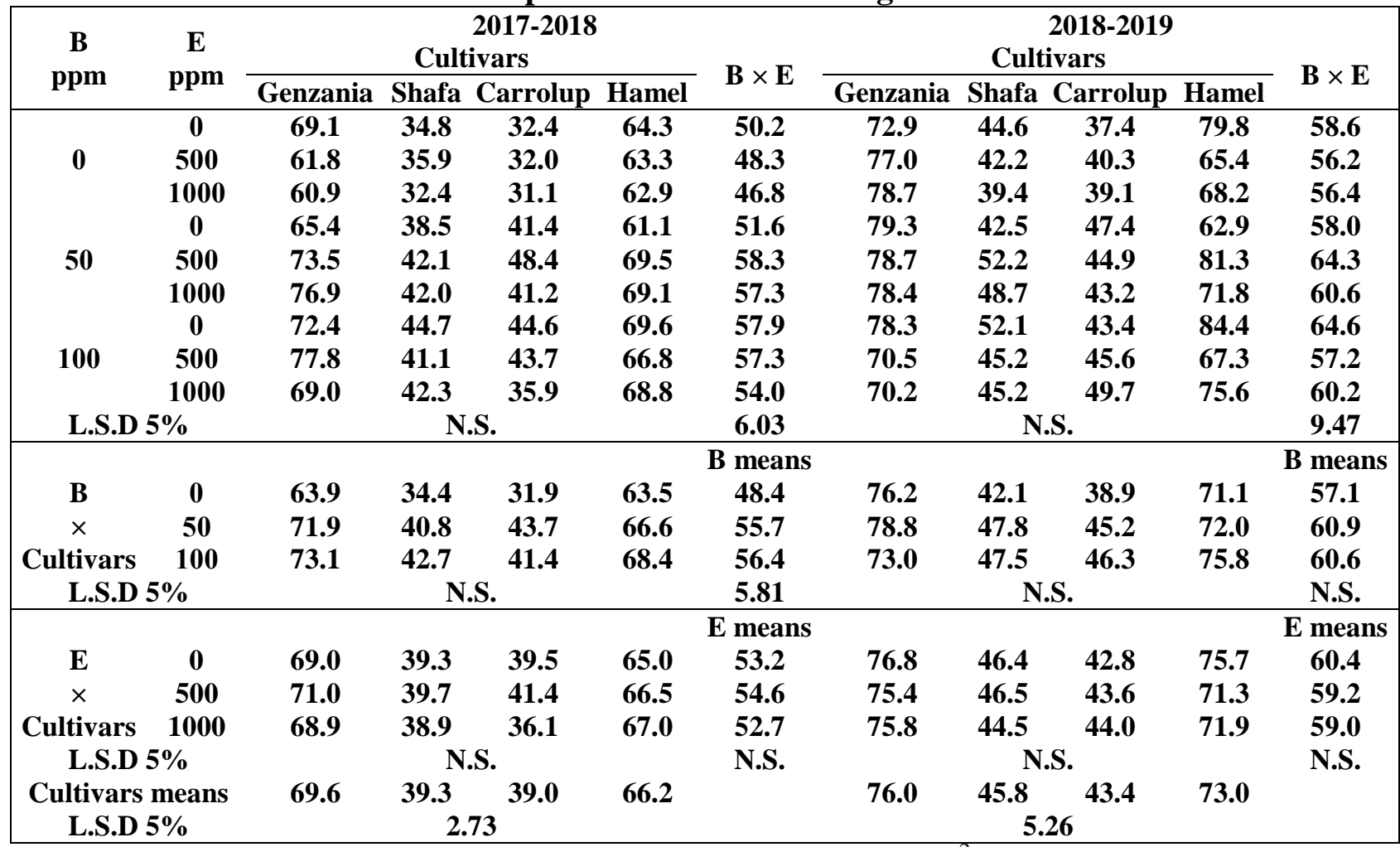

\section{Single grain weight $(\mathbf{m g})$}

The results in the Table 7 showed that Carrolup produced the highest mean of the Single grain weight $(35.7 \mathrm{mg})$ in the first season, significantly higher than Hamel and Genzania which had the lowest mean (28.0 $\mathrm{mg})$. In the second season, Shafa produced the highest mean of the Single grain weight (36.4 $\mathrm{mg}$ ) superior to the other cultivars, while Genzania had the lowest mean (26.4 mg). These differences could be due to the differences genotype of cultivars that led to the different efficiency of metabolism and transport of storage materials during the grain filling period. Dumlupinar et al., (14) and Chappell et al., (11) found that oat genotypes differed in grain weight. The data shows that there were negative effects of ethephon on the Single grain weight (Table 7). There were significant decreases less than control with $8.2 \%$ at the concentration $1000 \mathrm{ppm}$ ethephon in the first season, with $8.2 \%$ and $8.5 \%$ at concentrations 500 and 1000 ppm of ethephon in the second season. The decreases could be attributed to the increases in the number of the active tillers $\mathrm{m}^{-2}$ caused by ethephon (Table 5), which increased competition for energy and nutrients, so that reduced the amount of storage materials that reaches the grain during grain filling period. The results indicated that single grain weight significantly increased with effect of boron in the second season with 50 ppm concentration with $8.4 \%$ compared to the control treatment (Table 7). This increase could be due to the important role of boron in carbohydrate metabolism and transport through cellular membranes (8). Data in Table 7 show significant effects of the interaction between the cultivars and boron concentrations on single grain weight in both seasons. In the first season, Carrolup with $100 \mathrm{ppm}$ of boron was recorded the highest value of single grain weight $(38.7 \mathrm{mg})$, while Hamel with $0 \mathrm{ppm}$ of boron recorded the lowest value $(25.4 \mathrm{mg})$. In the second season, Carrolup with $50 \mathrm{ppm}$ of boron recorded the highest value of single grain weight $(38.9 \mathrm{mg})$, while Genzania with 0 ppm recorded the lowest $(24.8 \mathrm{mg})$. Significant effects were found in the interaction between the ethephon and boron 
concentrations on the single grain weight in the first season only (Table 7). The treatment of 0 ppm ethephon with 100 ppm boron

Table 7. Effect of boron and ethephon on the Single grain weight (mg) of four oat cultivars

\begin{tabular}{|c|c|c|c|c|c|c|c|c|c|c|c|}
\hline \multirow{3}{*}{$\begin{array}{c}\text { B } \\
\text { ppm }\end{array}$} & \multirow{3}{*}{$\begin{array}{c}\mathbf{E} \\
\text { ppm }\end{array}$} & \multicolumn{5}{|c|}{ 2017-2018 } & \multicolumn{5}{|c|}{ 2018-2019 } \\
\hline & & \multicolumn{4}{|c|}{ Cultivars } & \multirow{2}{*}{$\mathbf{B} \times \mathbf{E}$} & \multicolumn{4}{|c|}{ Cultivars } & \multirow{2}{*}{$\mathbf{B} \times \mathbf{E}$} \\
\hline & & Genzania & Shafa & Carrolu & Hamel & & Genzania & Shafa & Carrolup & Hamel & \\
\hline \multirow{3}{*}{$\mathbf{0}$} & $\mathbf{0}$ & 27.7 & 29.7 & 32.5 & 24.9 & 28.7 & 28.6 & 36.5 & 31.8 & 29.9 & 31.7 \\
\hline & 500 & 28.1 & 34.3 & 36.7 & 28.6 & 31.9 & 24.8 & 35.0 & 28.4 & 29.0 & 29.3 \\
\hline & 1000 & 23.5 & 30.1 & 31.8 & 22.6 & 27.0 & 21.1 & 34.1 & 32.3 & 24.5 & 28.0 \\
\hline \multirow{3}{*}{50} & $\mathbf{0}$ & 31.1 & 39.4 & 35.4 & 29.9 & 34.0 & 27.6 & 37.9 & 40.0 & 30.9 & 34.1 \\
\hline & 500 & 27.1 & 35.6 & 34.1 & 28.4 & 31.3 & 27.4 & 32.0 & 37.2 & 26.7 & 30.8 \\
\hline & 1000 & 25.7 & 38.4 & 34.8 & 26.8 & 31.4 & 24.6 & 35.7 & 39.4 & 26.3 & 31.5 \\
\hline \multirow{3}{*}{100} & $\mathbf{0}$ & 34.1 & 36.4 & 38.2 & 32.1 & 35.2 & 26.8 & 38.9 & 35.2 & 29.1 & 32.5 \\
\hline & 500 & 29.0 & 29.8 & 39.4 & 31.2 & 32.4 & 28.9 & 37.1 & 30.6 & 24.3 & 30.2 \\
\hline & 1000 & 25.5 & 31.8 & 38.5 & 29.8 & 31.4 & 28.1 & 39.9 & 28.3 & 25.6 & 30.5 \\
\hline \multicolumn{2}{|c|}{ L.S.D 5\% } & \multicolumn{3}{|c|}{ N.S. } & \multirow{2}{*}{\multicolumn{2}{|c|}{3.51}} & \multirow{2}{*}{\multicolumn{4}{|c|}{ N.S. }} & N.S. \\
\hline & \multicolumn{4}{|c|}{ B means } & & & & & & B means \\
\hline B & $\mathbf{0}$ & 26.5 & 31.4 & 33.7 & 25.4 & 29.2 & 24.8 & 35.2 & 30.8 & 27.8 & 29.7 \\
\hline$x$ & 50 & 28.0 & 37.8 & 34.8 & 28.3 & 32.2 & 26.5 & 35.2 & 38.9 & 28.0 & 32.2 \\
\hline Cultivars & 100 & 29.5 & 32.7 & 38.7 & 31.0 & 33.0 & 27.9 & 38.6 & 31.4 & 26.3 & 31.1 \\
\hline \multicolumn{2}{|c|}{ L.S.D $5 \%$} & \multicolumn{3}{|c|}{4.09} & & N.S. & \multicolumn{3}{|c|}{3.22} & & 1.73 \\
\hline & & \multicolumn{9}{|c|}{ E means } & E means \\
\hline $\mathbf{E}$ & $\mathbf{0}$ & 31.0 & 35.2 & 35.4 & 29.0 & 32.6 & 27.7 & 37.8 & 35.7 & 30.0 & 32.8 \\
\hline$x$ & 500 & 28.1 & 33.3 & 36.7 & 29.4 & 31.9 & 27.0 & 34.7 & 32.1 & 26.7 & 30.1 \\
\hline Cultivars & 1000 & 24.9 & 33.4 & 35.0 & 26.4 & 29.9 & 24.6 & 36.6 & 33.3 & 25.5 & 30.0 \\
\hline \multirow{3}{*}{\multicolumn{2}{|c|}{$\begin{array}{c}\text { L.S.D 5\% } \\
\text { Cultivars means } \\
\text { L.S.D 5\% }\end{array}$}} & \multicolumn{4}{|c|}{ N.S. } & 1.45 & \multicolumn{4}{|c|}{ N.S. } & 2.13 \\
\hline & & 28.0 & 34.0 & 35.7 & 28.2 & & 26.4 & 36.4 & 33.7 & 27.4 & \\
\hline & & & 2. & & & & & 2.7 & & & \\
\hline
\end{tabular}

\section{Grain yield ( $\left.\mathrm{t} \mathrm{ha}^{-1}\right)$}

The results in Table 8 shows that Genzania recorded the highest average grain yield $(6.512$ and $5.565 \mathrm{t} \mathrm{ha}^{-1}$ ) in the two seasons respectively, significantly highest than other cultivars in the first season, highest than Shafa and Carrolup in the second season, while Shafa recorded the lowest average $\left(5.011 \mathrm{t} \mathrm{ha}^{-}\right.$ ${ }^{1}$ ) in the first season, Carrolup recorded the lowest average (4.113 $\left.\mathrm{t} \mathrm{ha}^{-1}\right)$ in the second season. Genzania's superiority could be attributed to its superiority in the number of grains head ${ }^{-1}$ (Table 6). The results were consistent with the findings by Elsahookie et al., (15) about the differences among oat cultivars in the grain yield and Genzania superiority. The ethephon spraying had a significant effect on the grain yield for the first season only (Table 8). Grain yield increased with $9.15 \%$ more than control, at $50 \mathrm{ppm}$ ethephon. This increase could be due to the increase number of active tillers $\mathrm{m}^{-2}$ (Table 5). At concentration of $1000 \mathrm{ppm}$ ethephon, grain yield decreased significantly lower than grain yield at $50 \mathrm{ppm}$ ethephon, and non-significant decrease lower than grain yield at control. These results agreement with the results of recorded the highest value $(35.2 \mathrm{mg})$ while the treatment of $1000 \mathrm{ppm}$ ethephon with $0 \mathrm{ppm}$ boron recorded the lowest value $(27.0 \mathrm{mg})$.
Taylor et al., (24) who showed an increase grain yield of barley for one season from several seasons, when the low level of ethephon was used, and a decrease grain yield when using the high level of ethephon. Data in Table 8 indicates significant positive effects of boron on the grain yield in both seasons. Boron spraying was led to significantly increases over the control with $27.81 \%$ and $33.75 \%$ at boron concentrations 50 and 100 ppm respectively, in the first season, as well in the second season, the increase was20.17 and $12.45 \%$ at the two concentrations respectively, but there was no significant difference between 50 and 100 ppm boron. The increases of grain yield in the first season could be due to an increase of the number of grains head ${ }^{-1}$ (Table 6), as well the increases in the second season could be due to the increase of single grain weight (Table 7 ). These results were consistent with Castagnara et al., (9) with regard to the increase grain yield of oat by boron effect. There were significant effects of interaction between the ethephon and boron concentrations on the grain yield in the two seasons (Table 8). In the first season, the combination of 500 ppm ethephon with 100 
ppm boron had the highest grain yield $(6.425 \mathrm{t}$ $\mathrm{ha}^{-1}$ ). In the second season, the combination of 500 ppm ethephon with $50 \mathrm{ppm}$ boron had the highest grain yield $\left(5.982 \quad \mathrm{t} \mathrm{ha}^{-1}\right)$. The combination of $1000 \mathrm{ppm}$ ethephon with 0 ppm boron had the lowest grain yield, reached 3.955 and $4.255 \mathrm{t} \mathrm{ha}^{-1}$ in the two seasons respectively.

Table 8. Effect of boron and ethephon on the grain yield $\left(\mathrm{t} \mathrm{ha}^{-1}\right)$ of four oat cultivars

\begin{tabular}{|c|c|c|c|c|c|c|c|c|c|c|c|}
\hline \multirow{3}{*}{$\begin{array}{c}\text { B } \\
\text { ppm }\end{array}$} & \multirow{3}{*}{$\begin{array}{c}\mathbf{E} \\
\mathbf{p p m}\end{array}$} & \multicolumn{5}{|c|}{$2017-2018$} & \multicolumn{5}{|c|}{ 2018-2019 } \\
\hline & & \multicolumn{4}{|c|}{ Cultivars } & \multirow{2}{*}{$\mathbf{B} \times \mathbf{E}$} & \multicolumn{4}{|c|}{ Cultivars } & \multirow{2}{*}{$\mathbf{B} \times \mathbf{E}$} \\
\hline & & Genzania & Shafa & Carrolup & Hamel & & Genzania & Shafa & Carrolup & Hamel & \\
\hline \multirow{3}{*}{ ( } & $\mathbf{0}$ & 6.140 & 3.454 & 4.030 & 4.666 & 4.572 & 6.032 & 3.780 & 3.420 & 5.664 & 4.724 \\
\hline & 500 & 5.934 & 4.928 & 4.779 & 5.595 & 5.309 & 5.458 & 4.168 & 2.789 & 5.076 & 4.373 \\
\hline & 1000 & 4.738 & 3.911 & 3.049 & 4.121 & 3.955 & 4.509 & 4.212 & 3.431 & 4.750 & 4.225 \\
\hline & $\mathbf{0}$ & 6.548 & 5.161 & 5.361 & 4.945 & 5.504 & 6.159 & 4.359 & 4.233 & 4.379 & 4.782 \\
\hline \multirow[t]{3}{*}{50} & 500 & 7.030 & 5.931 & 6.085 & 5.987 & 6.258 & 6.764 & 5.209 & 5.863 & 6.093 & 5.982 \\
\hline & 1000 & 6.875 & 6.278 & 4.893 & 5.653 & 5.925 & 4.828 & 5.944 & 5.310 & 4.908 & 5.248 \\
\hline & $\mathbf{0}$ & 7.783 & 5.567 & 6.288 & 5.985 & 6.406 & 4.686 & 4.800 & 4.052 & 5.322 & 4.715 \\
\hline \multirow[t]{2}{*}{100} & 500 & 7.718 & 4.654 & 7.043 & 6.286 & 6.425 & 6.306 & 5.366 & 3.453 & 4.183 & 4.827 \\
\hline & 1000 & 5.838 & 5.215 & 5.353 & 6.326 & 5.683 & 5.340 & 6.014 & 4.466 & 5.940 & 5.440 \\
\hline \multicolumn{2}{|c|}{ L.S.D $5 \%$} & \multirow{2}{*}{\multicolumn{3}{|c|}{ N.S. }} & \multirow{2}{*}{\multicolumn{2}{|c|}{$\frac{0.8834}{\text { B means }}$}} & \multicolumn{3}{|c|}{ N.S. } & \multirow{2}{*}{\multicolumn{2}{|c|}{$\frac{0.6753}{\text { B means }}$}} \\
\hline & & & & & & & & & & & \\
\hline B & $\mathbf{0}$ & 5.604 & 4.098 & 3.953 & 4.794 & 4.612 & 5.333 & 4.053 & 3.214 & 5.163 & 4.441 \\
\hline$x$ & 50 & 6.817 & 5.790 & 5.446 & 5.528 & 5.895 & 5.917 & 5.171 & 5.135 & 5.127 & 5.337 \\
\hline Cultivars & 100 & 7.113 & 5.145 & 6.228 & 6.199 & 6.171 & 5.444 & 5.393 & 3.990 & 5.148 & 4.994 \\
\hline \multicolumn{2}{|c|}{ L.S.D $5 \%$} & \multicolumn{3}{|c|}{ N.S. } & \multirow{2}{*}{\multicolumn{2}{|c|}{0.8853}} & \multicolumn{3}{|c|}{ N.S. } & \multirow{2}{*}{\multicolumn{2}{|c|}{$\begin{array}{c}0.4706 \\
\text { E means }\end{array}$}} \\
\hline & & & & & & & & & & & \\
\hline $\mathbf{E}$ & $\mathbf{0}$ & 6.824 & 4.727 & 5.226 & 5.198 & 5.494 & 26 & 4.313 & 3.902 & 5.122 & 4.740 \\
\hline$x$ & 500 & 6.894 & 5.171 & 5.969 & 5.956 & 5.997 & 6.176 & 4.914 & 4.035 & 5.117 & 5.061 \\
\hline Cultivars & 1000 & 5.817 & 5.135 & 4.432 & 5.367 & \multirow{4}{*}{$\begin{array}{c}5.188 \\
0.3167\end{array}$} & 4.892 & 5.390 & 4.402 & 5.200 & 4.971 \\
\hline \multirow{3}{*}{\multicolumn{2}{|c|}{$\begin{array}{c}\text { L.S.D 5\% } \\
\text { Cultivars means } \\
\text { L.S.D 5\% } \\
\end{array}$}} & \multicolumn{3}{|c|}{ N.S. } & & & \multicolumn{3}{|c|}{ N.S. } & & \multirow[t]{3}{*}{ N.S. } \\
\hline & & 6.512 & 5.011 & 5.209 & 5.507 & & 5.565 & 4.872 & 4.113 & 5.146 & \\
\hline & & \multicolumn{4}{|c|}{0.4600} & & \multicolumn{4}{|c|}{0.5605} & \\
\hline
\end{tabular}

\section{REFERENCES}

1. Abood, N. M. 2017. Exogenous application of Ethephon effects on some growth and yield characteristics of sorghum (Sorghum bicolor L. Moench). Al-Anbar J. of Agr. Sci. 15 (2): 113

2. Ali, N., T. Jan, M. Z. Afridi, F. Munsif and M. Saeed. 2016. Evaluation of phonological characteristics of oat genotype grown under agro-ecology condition of Peshawar valley. International Journal of Agricultural and Environmental Research. 2(1): 48-55

3. Al-Naqeeb M. A. and M. A., Hashim. 2016. Effect of boron and ethephon in growth and yield of bread wheat. The Iraqi Journal of Agricultural Sciences, 47(1). 166-176

4. Arenhardt, E. G., J. A. G. Silva, L. G. Arenhardt, D. R. Silva, M. E. Gzergorczick, G. P. Ceolin, C. Stulp, R. G. Figueiredo and A. C. Oliveira. 2017. Technical and agronomic efficiency of oat cultivars as a function of nitrogen availability. Jaboticabal. 45(3): 257270

5. Attia, A. N. E., M. S. A. Sultan, M. A. Badawi and A. A. K. Alfahdawey. 2015. Morphological identification of some wheat varieties and its crosses. J. Plant Production, Mansoura Univ. 6 (6):
$889-901$

6. Berry, P. M., M. Sterling, J. Spink, C. J. Baker, R. Sylvester-Bradley, S. J. Mooney, A. R. Tams and A. R. Ennos. 2004. Understanding and reducing lodging in cereals. Adv. Agron. 84: 217-271

7. Blevins, D. G. and K. M. Lukaszewski. 1994. Proposed physiologic functions of boron in plants pertinent to animal and human metabolism. Environ Health Perspect. 102(Suppl 7): 31-33

8. Cara, F. A., E. Sánchez, J. M. Ruiz and L. Romero. 2002. Is phenol oxidation responsible for the short-term effects of boron deficiency on plasma-membrane permeability and function in squash roots? Plant Physiology and Biochemistry. 40(10): 853-858

9. Castagnara, D., A. Krutzmann, T. Zoz, F. Steiner, A. M. C. Castro, M. Neres and P. S. R. Oliveira. 2012. Effect of boron and zinc fertilization on white oats grown in soil with average content of these nutrients. Revista Brasileira de Zootecnia. 41 (7): 1598-1607.

10. Chandiposha M. and F. Chivende. 2014. Effect of ethephon and planting density on lodged plant percentage and crop yield in maize (Zea mays L.). African Journal of Plant Science. 8(2): 113-117 
11. Chappell, A., K. P. Scott, I. A. Griffiths, A. A. Cowan, C. Hawes, J. Wishart and P. Martin. 2017. The agronomic performance and nutritional content of oat and barley varieties grown in a northern maritime environment depends on variety and growing conditions. Journal of Cereal Science. 74: 1-10

12. Chen, X. G., C. Y. Shi, Y. P. Yin, Z. L. Wang, Y.H. Shi, D.L. Peng, Y. L. Ni and T. Cai. 2011. Relationship between lignin metabolism and lodging resistance in wheat. Acta Agronomica Sinica. 37(9): 1616-1622

13. Dabhi, M. S., M. R. Patel, C. R. Chaudhari, V. N. Patel and P. M. Patel. 2017. Response of oat (Avena sativa L.) varieties to methods of sowing and nitrogen levels on forage yield and quality. International Journal of Chemical Studies. 5(4): 683-686

14. Dumlupinar, Z., H. Karakuzulu, M.B. Demirtas, M. Ugurer, H. Gezging, T. Dokuyucu and A. Akkaya, 2015. A heterosis study for some agronomic traits in oat. Journal of Agricultural Sciences, 21: 414-419

15. Elsahookie, M. M., N. Younis and M. J. Al-Khafajy. 2013. Performance, variance components and heritability of oats cultivars under irrigation intervals. The Iraqi Journal of Agricultural Sciences. 44(1): 1-15

16. Foster, K. R., D. M. Reid and R. P. Pharis. 1992. Ethylene biosynthesis and ethephon metabolism and transport in barley. Crop Science. 32 (6): 1345-1352

17. Kelbert, A. J., D. Spaner, K. G. Briggs and J. R. King. 2004. Screening for lodging resistance in spring wheat breeding programmes. Plant Breeding. 123(4): 349-354 18. Maral, H., Z. Dumlupinar, T. Dokuyucu and A. Akkaya. 2013. Response of six oat (Avena sativa L.) cultivars to nitrogen fertilization for agronomical traits. Turkish Journal of Field Crops. 18(2): 254-259
19. Midha, L. K., B. S. Duhan and S. Arya. 2015. Performance of promising entries of oat (Avena sativa L.) under different nitrogen levels. Forage Res. 41 (2): 122-125

20. Sampson, D. R., 1972. Evaluation of nine oat varieties as parents in breeding for short stout straw with high grain yield using F1, F2, and F3 bulked progenies. Canadian Journal of Plant Science. 52(1): 21-28

21. Shekoofa, A. and Y. Emam. 2008. Plant growth regulator (ethephon) Alters maize (Zea mays L.) Growth, water use and grain yield under water stress. Journal of agronomy. 7(1): 41-48.

22. Siloriya, P. N., G. S. Rathi and V. D. Meena. 2014. Relative performance of oat (Avena sativa $\mathrm{L}$.) varieties for their growth and seed yield. African Journal of Agricultural Research. 9(3): 425-431

23. Stobbe, E. H., J. Moes, R. W. Bahry, R. Visser and A. Iverson. 1992. Environment, cultivar, and ethephon rate interactions in barley. Agronomy Journal. 84 (5): 789-794

24. Taylor, J. S., K. R. Foster and C. D. Caldwell. 1991. Ethephon effects on barley in central Alberta. Canadian Journal of Plant Science. 71(4): 983-995

25. Tripathi, S. C., K. D. Sayre, J. N Kaul and R. S Narang. 2004. Lodging behavior and yield potential of spring wheat (Triticum aestivum L.): effects of ethephon and genotypes. Field Crops Research. 87(2-3): 207-220

26. Wei, X. Y., M. C. Zhang and Z. H. Li. 2011. Differences in responding sensitivity to ethephon among different maize genotypes. Acta. Agron. Sin. 37(10):1819-1827

27. Wiersma, D. W., E. S. Oplinger and S. O. Guy. 1985. Environment and cultivar effects on winter wheat response to ethephon plant growth regulator1. Agron. J. 78(5): 761-764

28. Zadoks, J. C., T. T. Chang and C. F. Konzak. 1974. A decimal code for the growth stages of cereals. Weed Res. 14: 415-421. 